\title{
Neutrophil Gelatinase-Associated Lipocalin
}

National Cancer Institute

\section{Source}

National Cancer Institute. Neutrophil Gelatinase-Associated Lipocalin. NCI Thesaurus.

Code C71452.

Neutrophil gelatinase-associated lipocalin (198 aa, $23 \mathrm{kDa}$ ) is encoded by the human LCN2 gene. This protein may play a role in iron transport, apoptosis, and innate immunity. 